\title{
Microbial Load and Antibiotic Resistance of Escherichia coli and Staphylococcus aureus Isolated from Ready-to-Eat (RTE) Khebab Sold on a University Campus and Its Environs in Ghana
}

\author{
Azumah Ayamah $\left(\mathbb{D},{ }^{1,2}\right.$ Augustina Angelina Sylverken ${ }^{(D)},{ }^{2}$ and Linda Aurelia Ofori ${ }^{2}{ }^{2}$ \\ ${ }^{1}$ Department of Crop and Soil Sciences, Faculty of Agriculture, Kwame Nkrumah University of Science and Technology, \\ Kumasi, Ghana \\ ${ }^{2}$ Department of Theoretical and Applied Biology, Faculty of Biosciences, Kwame Nkrumah University of Science and Technology, \\ Kumasi, Ghana \\ Correspondence should be addressed to Azumah Ayamah; aazumah.canr@knust.edu.gh
}

Received 9 September 2021; Accepted 26 November 2021; Published 29 December 2021

Academic Editor: Shaaban H. Moussa

Copyright (c) 2021 Azumah Ayamah et al. This is an open access article distributed under the Creative Commons Attribution License, which permits unrestricted use, distribution, and reproduction in any medium, provided the original work is properly cited.

\begin{abstract}
The demand for ready-to-eat (RTE) foods is handy to busy urban dwellers. Handling, processing, and selling are known to contaminate these foods and cause foodborne outbreaks. This study assessed a load of S. aureus and E. coli in khebabs (beef, chevon, and gizzard) sold on the KNUST campus and its environs and how resistant they are to clinically relevant antimicrobial agents. Thirty-six (36) khebab samples were purchased from vendors at Kotei, Ayeduase, Kentinkrono, Boadi, KNUST campus, and Ayigya. They were analyzed for $S$. aureus and E. coli and their resistance to clinically relevant antimicrobial agents checked using standard methods. S. aureus and E. coli load ranged from 4.09 to $5.96 \mathrm{CFU} / \mathrm{g}$ and 1.79 to $6.12 \mathrm{MPN} / \mathrm{g}$ in beef, 4.02 to 6.01 CFU/g and 1.99 to $4.44 \mathrm{MPN} / \mathrm{g}$ in chevon, and 5.37 to $6.18 \mathrm{CFU} / \mathrm{g}$ and 1.79 to $6.10 \mathrm{MPN} / \mathrm{g}$ in gizzard khebabs in the different locations. E. coli $(n=27)$ were multiresistant to ampicillin, tetracycline, gentamicin, cefuroxime, ceftriaxone, cefotaxime, and cotrimoxazole $(51.85 \%)$ and susceptible to chloramphenicol $(100 \%)$. S. aureus $(n=36)$ isolates were multiresistant to penicillin, tetracycline, flucloxacillin, cefuroxime, ampicillin (97.22\%), erythromycin (75\%), cotrimoxazole (86.11\%), and gentamicin (69.44\%). It can therefore be concluded that the majority of khebabs from the KNUST campus and its environs were contaminated with $S$. aureus and E. coli above the acceptable standard limits $\left(\leq 4 \log _{10}\right.$ CFU/g and $<2 \log _{10} \mathrm{MPN} / \mathrm{g}$, respectively). Also, the $S$. aureus and E. coli isolated were multiresistant to the antibiotics tested and could be a medium for the transmission of antibioticresistant bacteria and therefore expose consumers to a high risk of contracting foodborne infections with drug-resistant strains.
\end{abstract}

\section{Introduction}

Ready-to-eat (RTE) foods have been defined as foods that do not require further preparation with exception of reheating [1]. These RTE foods are usually consumed raw or cooked, or hot or cold without further heat treatment $[2,3]$. Khebab is a popular ready-to-eat street-vended meat in Ghana, which is easily accessible to most Ghanaians. The khebab is usually prepared using meat from cow, goat, sheep, chicken, etc. The khebab may contain high protein or carbohydrate, high moisture content, or low acidity, which provides a suitable medium for the rapid growth of microorganism, therefore making it potentially hazardous food. Because it provides a medium for rapid microorganism's growth, microbial pathogens or toxins can affect consumer's health and may even lead to death when they are contaminated [4].

$S$. aureus and $E$. coli have been found to contaminate readyto-eat foods [5-9]. They have the ability to survive on hands and other surfaces and are therefore transferred to foods [10]. Feglo and Sakyi [11] recorded different levels of S. aureus, E. coli, and other bacteria in different ready-to-eat foods in the Kumasi metropolis of Ghana. S. aureus is a major foodborne pathogen in ready-to-eat foods responsible for foodborne infections across the globe $[12,13]$. It grows rapidly under 
room temperature and produces toxins that cause the infections. Every year, about 241,000 foodborne diseases of S. aureus are reported in the United States $[14,15]$. Also, China recorded $12.5 \%$ foodborne diseases associated with S. aureus in 2013 [14]. E. coli on the other hand is one of the most dangerous foodborne pathogens $[16,17]$. It produces one or more types of cytotoxins such as shiga toxin (Stx) or vero-cytotoxin (VT). Those producing Stx and VT are referred to as shiga toxinproducing E. coli (STEC) and vero-cytoxigenic E. coli (VTEC), respectively [18]. According to Monaghan et al. [19], STEC is one of the most important foodborne pathogens to emerge within the past two decades. It is a frequent cause of foodborne diarrhea outbreak [20-22]. In North America, Europe, Asia, and Africa, E. coli, particularly serotype O157:H7, is an important food-borne pathogen responsible for gastroenteritis epidemics [23, 24]. In 2011, the CDC reported that shiga toxinproducing Escherichia coli (STEC) O157 infections cause more than 63,000 illnesses, 2,100 hospitalizations, and 20 deaths in the United States [15]. In the world, STEC O157 is the most common serotype associated with human gastrointestinal illness and ranks third in the cause of bacterial foodborne-related hospitalizations in the United States $[15,25]$. Individuals infected with STEC usually develop hemolytic uremic syndrome, hemolytic anemia, and thrombocytopenia that can be fatal [26].

The increased contaminations of RTE foods in the society could be linked to the increased mobility of people due to urbanization, larger number of itinerant workers, and less home activities have resulted in large percentage of the population depending on RTE foods for employment and food. This situation, however, resulted that food sanitary measures and proper handling have been transferred from individual and families to the food vendors who rarely enforce such practices $[27,28]$. Majority of these vendors are unaware of improper handling of food and their role in the transmission of infections $[29,30]$. Most RTE foods are also sold under insanitary conditions that make them prone to contamination [4, 31-33]. Additionally, most RTE foods are sold openly, with little or no covering, and are therefore easily contaminated by flies and dust in the environment [34].

Besides foodborne contamination, the emergence of antimicrobial-resistant bacteria is a great challenge to public health. The indiscriminate uses of antimicrobials in animals and humans have led to the development of antimicrobialresistant microorganisms [35]. In recent times, more and more multidrug-resistant (MDR) $S$. aureus food poisoning outbreaks have been reported [36-39]. There are limited data on antimicrobial resistance of $S$. aureus and $E$. coli foods in Ghana. It is with this background that this study was conducted to assess the $S$. aureus and E. coli loads in khebabs sold on the KNUST campus and its environs and how resistant they are to clinically relevant antimicrobial agents.

\section{Materials and Methods}

2.1. Study Design. A cross-sectional study was conducted in 2018 to assess the $S$. aureus and E. coli loads in khebabs sold on the KNUST campus and its environs, and how resistant they are to clinically relevant antimicrobial agents [40].
2.2. Study Location. The study was conducted in the KNUST campus and its environs in the Oforikrom $\mathrm{Mu}$ nicipal Assembly, Kumasi, Ghana (Figure 1). According to Ababio and Adi [41], the KNUST campus and its environs are one of the communities in Kumasi with high population of food vendors because of the socioeconomic activities that take place in this area. Majority of students, staff, and indigenous people residing on the KNUST campus and its environs patronize these ready-to-eat foods.

2.3. Collection of Samples. Samples of khebab made from beef, chevon, and gizzard were purchased from two vendors in each location. A purposive sampling technique was employed in the selection of the vendors. About one hundred grams of the khebabs were purchased from each vendor into a sterile Ziploc bag. The purchased khebab samples were kept in an ice chest with ice packs and transported immediately to the laboratory and stored at $4^{\circ} \mathrm{C}$ and analyzed the following day [40].

\section{Microbiological Analysis}

3.1. Sample Analysis. Serial dilutions of $10^{-1}$ to $10^{-5}$ of the sample were carried out by placing ten grams of each khebab sample into ninety milliliters of sterilized buffered peptone water (Oxoid CM 0009; Oxoid Ltd Basingstoke, Hampshire, England) and pulsified for 15 seconds [40].

3.2. Total Viable Count (TVC). Pour plate technique was employed to estimate the TVC of S. aureus using mannitol salt agar. Aliquot of $1 \mathrm{ml}$ from each of the dilutions for the khebab samples was placed into labeled petri dishes, and about $10 \mathrm{ml}$ of molten $\left(45^{\circ} \mathrm{C}\right)$ mannitol salt agar (Oxoid CM 0085; Oxoid Ltd Basingstoke, Hampshire, England) was poured into the labeled petri dishes. The plates were swirled slowly for uniform mixing, allowed to solidify, sealed with parafilm, and then incubated at $35^{\circ} \mathrm{C}$ for 24 hours. Colonies with yellow and pink zones observed indicated the presence of $S$. aureus, which were counted using colony counter (Stuart colony counter, UK). Colonies between 30 and 300 were used in their estimation by using the following formula:

$$
\mathrm{CFU}=\text { average colonies } \times \frac{\text { dilution factor }}{\text { aliquot plated }} \text { and expressed as } \mathrm{CFU} / \mathrm{g} \text {. }
$$

3.3. Isolation of S. aureus. Yellow and pink zone colonies on the mannitol salt agar were isolated onto nutrient agar as presumptive $S$. aureus [42].

3.4. Enumeration, Isolation, and Characterization of Escherichia coli. The most probable number (MPN) method was employed to enumerate the total E. coli in the khebab samples. One milliliter aliquot from each of the dilutions was inoculated into a $5 \mathrm{ml}$ sterile MacConkey Broth (Oxoid CM 0085; Oxoid Ltd Basingstoke, 


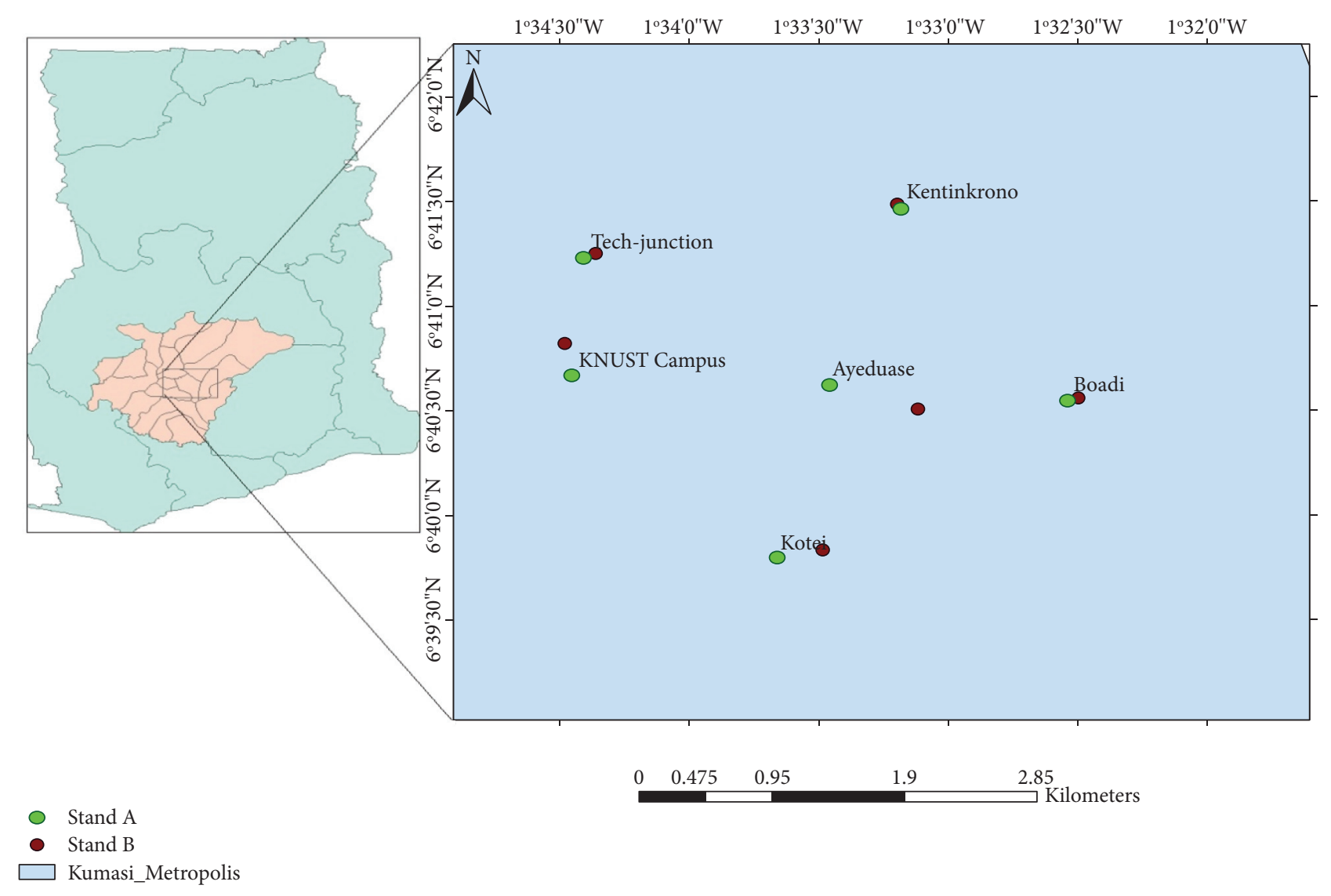

FIgURE 1: Map showing sampling locations.

Hampshire, England) and incubated at $44^{\circ} \mathrm{C}$ for 24 hours. Tubes showing colour change from purple to yellow after incubation were identified as presumptive positive for thermotolerant coliforms. From each of the positive tubes, $1 \mathrm{ml}$ was transferred into a test tube containing $5 \mathrm{ml}$ of sterile tryptophan broth (Scharlau 02-418; Scharlau chemie S.A, Barcelona, Spain) and incubated at $44^{\circ} \mathrm{C}$ for 24 hours. A drop of Kovacs' reagent was added to the overnight $(\mathrm{ON})$ culture tubes of tryptophan broth. All tubes showing a red ring development after gentle agitation denoted the presence of indole and were recorded as presumptive positive for thermotolerant coliforms (E. coli). Counts per gram were calculated from the most probable number (MPN) tables.

The tubes that showed ring colour development were further streaked on eosin methylene blue (EMB) agar media (Oxoid CM 0069; Oxoid Ltd Basingstoke, Hampshire, England) and incubated at $37^{\circ} \mathrm{C}$ for 24 hours and colonies with green metallic sheen indicated $E$. coli. The colonies were then subcultured into nutrient agar to obtain pure isolates.

Bacteria were characterized using an API 20E Biochemical Test Strip following manufacturer's manual (bioMérieux, France). All codes obtained were referenced to the API database for organism identification.
3.5. Antimicrobial Susceptibility of E. coli and S. aureus. Antimicrobial susceptibility of $E$. coli and $S$. aureus was determined by the Kirby Bauer agar disk diffusion method on Mueller-Hinton agar according to the protocol and guidelines of the European Committee on Antibiotic Susceptibility Testing [43].

Broth cultures of the isolates and Muller-Hinton agar (Oxoid CM 0337; Oxoid Ltd Basingstoke, Hants, United Kingdom) plates were prepared. The Muller-Hinton agar plates were streaked with the broth cultures with the help of a sterile swap and allowed to dry for 2-5 minutes. Sterile forceps were used to aseptically pick each of the antibiotic disks (Abtek Biologicals Ltd) and placed on each plate. The plates were labeled and incubated at $37^{\circ} \mathrm{C}$ for $24 \mathrm{hrs}$. The zone of inhibition (ZOI) was measured using a ruler, and data were recorded and interpreted according to the EUCAST breakpoints [44].

3.6. Statistical Analysis. The data collected were subjected to the analysis of variance (ANOVA) using Genstat statistical software version 12. Significant differences were assessed at $5 \%$ level of significance $(p=0.05)$. Where there was a significant difference, means were separated using the Fishers protected least significant difference (LSD) 
TABLe 1: Mean loads of E. coli and S. aureus in beef khebab sold on the KNUST campus and its environs.

\begin{tabular}{lcccc}
\hline Location & $\begin{array}{c}\text { Range of E. coli } \\
\text { load (MPN/g) }\end{array}$ & $\begin{array}{c}\text { Mean load of E. coli } \\
\left(\log _{10} \text { MPN/g) }\right.\end{array}$ & $\begin{array}{c}\text { Range of S. aureus } \\
\text { load }(\text { CFU/g) }\end{array}$ & $\begin{array}{c}\text { Mean load of } \\
\text { S. aureus }\left(\log _{10} \text { CFU/g) }\right.\end{array}$ \\
\hline Kotei & $0.00-9.30 \times 10^{5}$ & $3.77 \pm 2.94^{\mathrm{ab}}$ & $3.10 \times 10^{2}-1.44 \times 10^{6}$ & $4.09 \pm 1.47$ \\
Ayeduase & $9.00 \times 10^{4}-2.10 \times 10^{6}$ & $5.61 \pm 0.57^{\mathrm{b}}$ & $6.40 \times 10^{3}-2.96 \times 10^{7}$ & $5.12 \pm 1.81$ \\
Kentinkrono & $0.00-9.30 \times 10^{5}$ & $1.99 \pm 3.08^{\mathrm{a}}$ & $8.80 \times 10^{2}-9.60 \times 10^{6}$ & $5.46 \pm 1.52$ \\
Boadi & $0.00-2.30 \times 10^{5}$ & $1.79 \pm 2.77^{\mathrm{a}}$ & $3.70 \times 10^{3}-2.94 \times 10^{6}$ & $5.43 \pm 1.40$ \\
KNUST campus & $0.00-2.40 \times 10^{6}$ & $3.91 \pm 3.06^{\mathrm{ab}}$ & $6.40 \times 10^{2}-4.40 \times 10^{6}$ & $4.80 \pm 1.56$ \\
Ayigya & $2.30 \times 10^{5}-9.30 \times 10^{6}$ & $6.12 \pm 0.60^{\mathrm{b}}$ & $4.40 \times 10^{5}-1.94 \times 10^{6}$ & $5.96 \pm 0.24$ \\
CV (\%) & & 63.2 & & 27.8 \\
$p$ value & & 0.019 & & 0.323 \\
\hline
\end{tabular}

$\mathrm{MPN}=$ most probable number; $\mathrm{CFU}=$ colony-forming unit. Mean loads with the same letters are not significantly different $(p>0.05)$.

TABLE 2: Mean loads of E. coli and S. aureus in chevon khebab sold on the KNUST campus and its environs.

\begin{tabular}{lcccc}
\hline Location & $\begin{array}{c}\text { Range of E. coli } \\
\text { load (MPN/g) }\end{array}$ & $\begin{array}{c}\text { Mean load of E. coli } \\
\left(\log _{10} \text { MPN/g) }\right.\end{array}$ & $\begin{array}{c}\text { Range of S. aureus } \\
\text { load (CFU/g) }\end{array}$ & $\begin{array}{c}\text { Mean load of S. aureus } \\
\left(\log _{10} \text { CFU/g) }\right.\end{array}$ \\
\hline Kotei & $0.00-2.40 \times 10^{6}$ & $3.91 \pm 3.06$ & $3.60 \times 10^{3}-3.70 \times 10^{4}$ & $4.02 \pm 0.39^{\mathrm{a}}$ \\
Ayeduase & $0.00-9.30 \times 10^{6}$ & $4.44 \pm 3.45$ & $2.40 \times 10^{4}-2.88 \times 10^{7}$ & $6.01 \pm 1.31^{\mathrm{bc}}$ \\
Kentinkrono & $0.00-9.30 \times 10^{6}$ & $4.43 \pm 3.44$ & $1.80 \times 10^{5}-1.64 \times 10^{7}$ & $6.53 \pm 0.71^{\mathrm{c}}$ \\
Boadi & $0.00-9.30 \times 10^{5}$ & $1.99 \pm 3.08$ & $3.60 \times 10^{3}-1.40 \times 10^{6}$ & $4.82 \pm 1.13^{\mathrm{ab}}$ \\
KNUST campus & $0.00-4.30 \times 10^{6}$ & $3.99 \pm 3.14$ & $4.50 \times 10^{3}-1.28 \times 10^{7}$ & $5.71 \pm 1.62^{\mathrm{bc}}$ \\
Ayigya & $0.00-2.40 \times 10^{6}$ & $4.25 \pm 3.29$ & $4.60 \times 10^{3}-1.52 \times 10^{7}$ & $5.81 \pm 1.49^{\mathrm{bc}}$ \\
CV (\%) & & 84.7 & & 21.7 \\
$p$ value & & 0.779 & & 0.013 \\
\hline
\end{tabular}

$\mathrm{MPN}=$ most probable number; $\mathrm{CFU}=$ colony-forming unit. Mean loads with same letters are not significantly different $(p>0.05)$.

procedure. The data were logarithmically $\left(\log _{10}\right)$ transformed to minimize the variations associated with the enumeration techniques.

\section{Results}

4.1. Mean Load of E. coli and S. aureus in Beef Khebab. The beef khebab from the different locations recorded varying mean loads of $E$. coli ranging from 0.00 to $9.30 \times 10^{6}$ $\mathrm{MPN} / \mathrm{g}$ with those from Ayigya recording the highest load (6.12 $\log _{10} \mathrm{MPN} / \mathrm{g}$ ) and Boadi the lowest (1.79 $\left.\log _{10} \mathrm{MPN} / \mathrm{g}\right)$ (Table 1). E. coli load was significantly different $(p=0.019)$ and was above the Food Standards of Australia New Zealand (FSANZ) guidelines of ${ }^{<} 100 \mathrm{MPN} / \mathrm{g} \quad\left({ }^{<} 2 \log _{10} \mathrm{MPN} / \mathrm{g}\right)$. Nonetheless, the E. coli load in beef at Kentinkrono and Boadi was within the acceptable limit.

The mean load of $S$. aureus ranged from $3.10 \times 10^{2}$ to $2.96 \times 10^{7} \mathrm{CFU} / \mathrm{g}$ with no significant difference among them. Samples from Ayigya recorded the highest load of 5.96 $\log _{10} \mathrm{CFU} / \mathrm{g}$, whereas those from Kotei recorded the least load of $4.09 \log _{10} \mathrm{CFU} / \mathrm{g}$ (Table 1). S. aureus load was, however, above the FSANZ acceptable limit of $\leq 10^{4} \mathrm{CFU} / \mathrm{g}$ $(\leq 4 \log \mathrm{CFU} / \mathrm{g})$ for safe foods.

4.2. Mean Load of E. coli and S. aureus in Chevon Khebab. $E$. coli load in chevon khebab ranged from 0.00 to $9.30 \times 10^{6} \mathrm{MPN} / \mathrm{g}$ with Ayeduase recording the highest mean E. coli load of $4.44 \log _{10} \mathrm{MPN} / \mathrm{g}$ and Boadi the least (1.99 $\log \mathrm{MPN} / \mathrm{g}$ ) (Table 2). The differences were not significant $(p=0.779)$ but were above the FSANZ guidelines of $<100 \mathrm{MPN} / \mathrm{g}\left(<2 \log _{10} \mathrm{MPN} / \mathrm{g}\right)$ with the exception of Boadi, which was within the guidelines limit. Staphylococcus aureus ranged from $3.60 \times 10^{3}$ to $2.88 \times 10^{7} \mathrm{CFU} / \mathrm{g}$ in chevon khebab irrespective of the location. Samples from Kentinkrono recorded the highest mean load of $6.53 \log _{10} \mathrm{CFU} / \mathrm{g}$, whereas those from Kotei the least (4.02 $\log _{10} \mathrm{CFU} / \mathrm{g}$ ) (Table 2). The mean loads of $S$. aureus were significantly different $(p=0.013)$ and above the FSANZ acceptable limit of $\leq 10^{4} \mathrm{CFU} / \mathrm{g}(\leq 4 \mathrm{log}$ $\mathrm{CFU} / \mathrm{g})$.

4.3. Mean Load of E. coli and S. aureus in Gizzard Khebab. For the gizzard khebab, the mean load of E. coli for the locations ranged from 0.00 to $2.90 \times 10^{7} \mathrm{MPN} / \mathrm{g}$ with Kotei recording the highest mean load (6.10 $\left.\log _{10} \mathrm{MPN} / \mathrm{g}\right)$ and the least observed in Boadi (1.79 $\log _{10} \mathrm{MPN} / \mathrm{g}$ ). Although the mean load of $E$. coli in the gizzard khebab from the various locations was not significantly different $(p=0.207)$, it was above the FSANZ guidelines of $<100$ $\mathrm{MPN} / \mathrm{g}\left(<2 \log _{10} \mathrm{MPN} / \mathrm{g}\right)$, with the exception of Boadi, which had a mean $E$. coli load within the acceptable limit. S. aureus load ranged from $4.20 \times 10^{3}$ to $1.64 \times 10^{7} \mathrm{CFU} / \mathrm{g}$. Samples from Kentinkrono recorded the highest mean load (6.18 log CFU/g), whereas those from Kotei recorded 
TABLE 3: Mean load of E. coli and S. aureus in gizzard khebab sold on the KNUST campus and its environs.

\begin{tabular}{lcccc}
\hline Location & $\begin{array}{c}\text { Range of E. coli } \\
\text { load }(\mathrm{MPN} / \mathrm{g})\end{array}$ & $\begin{array}{c}\text { Mean load of } \\
\text { E. coli }\left(\log _{10} \text { MPN/g) }\right.\end{array}$ & Range (CFU/g) of S. aureus load & Mean load of S. aureus $\left(\mathrm{log}_{10}\right.$ CFU/g) \\
\hline Kotei & $2.30 \times 10^{5}-4.30 \times 10^{6}$ & $6.10 \pm 0.52$ & $1.52 \times 10^{4}-3.50 \times 10^{6}$ & $5.37 \pm 0.98$ \\
Ayeduase & $0.00-2.40 \times 10^{6}$ & $3.85 \pm 3.03$ & $4.20 \times 10^{3}-2.96 \times 10^{6}$ & $5.43 \pm 1.36$ \\
Kentinkrono & $0.00-2.90 \times 10^{7}$ & $2.94 \pm 3.85$ & $3.00 \times 10^{5}-1.64 \times 10^{7}$ & $6.18 \pm 0.81$ \\
Boadi & $0.00-2.40 \times 10^{5}$ & $1.79 \pm 2.78$ & $1.24 \times 10^{5}-1.76 \times 10^{6}$ & $5.80 \pm 0.54$ \\
KNUST campus & $0.00-1.50 \times 10^{6}$ & $4.05 \pm 3.14$ & $1.48 \times 10^{5}-9.60 \times 10^{6}$ & $5.82 \pm 0.65$ \\
Ayigya & $0.00-9.30 \times 10^{6}$ & $4.38 \pm 3.41$ & $7.40 \times 10^{3}-1.64 \times 10^{7}$ & $5.69 \pm 1.50$ \\
CV (\%) & & 79.1 & & 18.1 \\
$p$ value & & 0.207 & & 0.788 \\
\hline
\end{tabular}

$\mathrm{MPN}=$ most probable number; $\mathrm{CFU}=$ colony-forming unit.

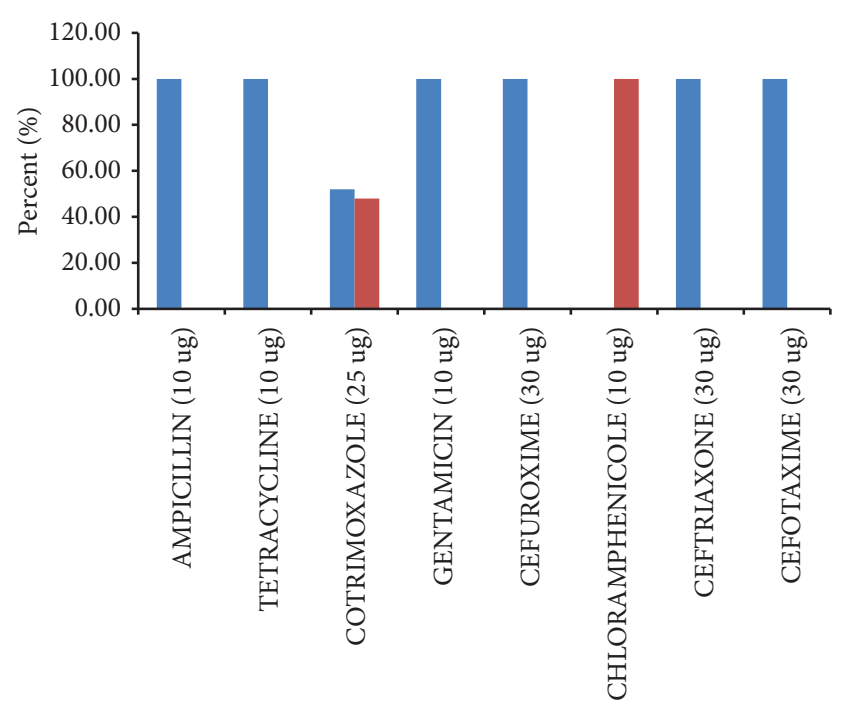

Antibiotics

- (\%) RESISTANCE

- (\%) SUSCCEPTIBILITY

FIGURE 2: A graph showing percentage resistance and susceptibility of E. coli.

the least (5.37 $\log _{10} \mathrm{CFU} / \mathrm{g}$ ) (Table 3 ). The mean load differences of $S$. aureus were statistically not significant $(p=0.788)$; however, they were above the FSANZ acceptable standard limit of $\leq 10^{4} \mathrm{CFU} / \mathrm{g}\left(\leq 4 \log _{10} \mathrm{CFU} / \mathrm{g}\right)$.

\subsection{Antimicrobial Susceptibility of E. coli and S. aureus from Khebab on KNUST Campus and Its Environs}

4.4.1. E. coli. Based on the British Society for Antimicrobial Chemotherapy (BSAC) Methods for Antimicrobial Susceptibility Testing, version 14, May 2015, E. coli $(n=27)$ were all resistant to the antibiotics tested with the exception of chloramphenicol, which was susceptible (Figure 2).

4.4.2. S. aureus. S. aureus $(n=36)$ was resistant to the antibiotics tested (ampicillin, tetracycline, gentamicin, cefuroxime, ceftriaxone and cefotaxime $=100 \%$, cotrimoxazole $=52 \%$ ) with the exception of few which were susceptible (chloramphenicole $=100 \%$ and cotrimoxazole $=48 \%$ ).

\section{Discussion}

5.1. Microbiological Quality. The mean E. coli count in the beef, chevon, and gizzard khebab samples from the various locations ranged from 1.79 to $6.12 \log _{10} \mathrm{MPN} / \mathrm{g}, 1.99$ to $4.44 \log _{10} \mathrm{MPN} / \mathrm{g}$, and 1.79 to $6.10 \log _{10} \mathrm{MPN} / \mathrm{g}$, respectively. The mean $E$. coli count for the khebab samples (beef, chevon, and gizzard) in the locations was above the standard acceptable limit, except Boadi, which was within the acceptable limit. The high count of E. coli in the khebab samples suggests a possible faecal contamination. This may be due to poor hygienic practices of the vendors. Hygienic practices such as protection of food from flies and dust, cleaning of fingernails, use of aprons, and head cups by street food vendors are one of the key measures that helps to prevent foodborne contamination [40]. But majority of street food vendors are uneducated and therefore lack the knowledge in safe food preparation and handling. As a result, they rarely adhere to hygienic practices and this might have accounted the high level of E. coli count in the khebab samples. Additionally, meat generally contains the necessary nutrients for microbial growth as well as their metabolism, making it prone to microbial contaminations. Thus, if the vendor does not practice proper hygiene, it facilitates the growth of the organism resulting in their high numbers [45]. According to Oladipo-Adekeye and Tabit [46], Carrasco et al. [47], and Wei et al. [48], poor sanitary practices by street food vendors results in food contaminations. The use of nonportable water by vendors during preparation or processing of the khebab could also contaminate the khebab with E. coli. E. coli is destroyed at a temperature above $70^{\circ} \mathrm{C}$, so their presence in the khebab samples could be that the khebabs were insufficiently heated (roasted) or grilled [49]. Bryan et al. [50] have reported similar high E. coli count of $6 \log _{10} \mathrm{CFU} / \mathrm{g}$ in street-vended foods. Djoulde et al. [51] also reported E. coli counts of 3.3 $\log _{10} \mathrm{CFU} / \mathrm{g}$ and $2.8 \log _{10} \mathrm{CFU} / \mathrm{g}$ in mobile and stationary food sellers, respectively, which are lower than the current findings but were above the permissible limit. Ologhobo et al. [52] also reported unsatisfactory levels of E. coli counts in-RTE beef $\left(3.3 \times 10^{4} \mathrm{CFU} / \mathrm{g}\right)$ and chicken $\left(3.4 \times 10^{5} \mathrm{CFU} / \mathrm{g}\right)$ "suya," which is lower than the current findings but above the permissible limit. Similar results of high E. coli count above the permissible limit have also 


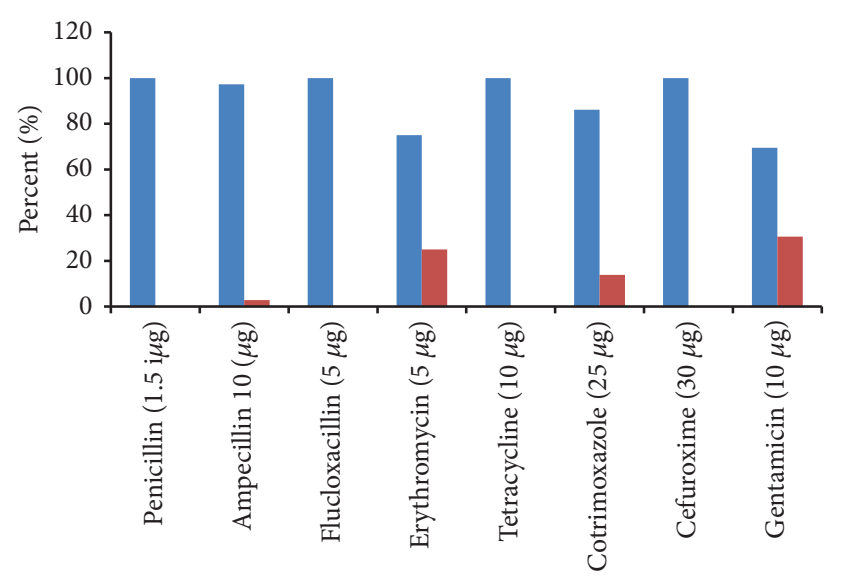

Antibiotics

- (\%) RESISTANCE

- (\%) SUSCEPTIBILITY

FIGURE 3: A graph showing percentage resistance and susceptibility of $S$. aureus.

been reported by Salihu et al. [53] in traditionally prepared ground beef.

The mean total viable count (TVC) of S. aureus in the beef, chevon, and gizzard khebabs in the locations was all above the standard acceptable limit of $\leq 10^{4} \mathrm{CFU} / \mathrm{g}(\leq 4$ $\log _{10}$ CFU/g). According to Bishop and Onyowoicho [54] and Gilbert and Harrison [55], S. aureus is a normal flora of the human skin. Therefore, the high levels of $S$. aureus in the khebab samples might be a cross-contamination from the vendor. Gay [56] also indicated that the presence of $S$. aureus in food is mainly a result of human contamination, which is normally from the human respiratory passages and the skin, as well as the superficial wounds on the human skin surfaces. But according to Levine [57], the TVC of microbes present in any food is not indicative of their safety for consumption, but it is a supreme importance of judging the hygienic conditions under which the foods had been prepared, handled, and stored. The current results are consistent with the findings of Hassan et al. [58], who reported microbial load of $S$. aureus ranging from 0.125 to $2.6 \times 10^{6} \mathrm{CFU} / \mathrm{g}$ in barbecue meat (suya). Bagumire and Karamuna [1] and Selvan et al. [59] also reported higher S. aureus count of 4.37 and $4.88 \log _{10} \mathrm{CFU} / \mathrm{g}$ in ready-to-eat beef and chicken samples, respectively. However, the current results are in contrast to the findings of Uzeh et al. [60] and Djoulde et al. [51] who reported relatively lower $S$. aureus count of $1.0 \times 10^{2}-12.0 \times 10^{2} \mathrm{CFU} / \mathrm{g}$ and $1.10 \log _{10} \mathrm{CFU} / \mathrm{g}$ in tsire-suya and roasted chicken, respectively.

5.2. Antimicrobial Susceptibility of S. aureus and E. coli Isolated from Khebab Samples. The antibiotic resistance pattern observed in the E. coli $(n=27)$ and S. aureus $(n=36)$ revealed a multiresistance to the antibiotics tested, although some of them were susceptible to few of the antibiotics tested (Figures 2 and 3). E. coli $(n=27)$ were $100 \%$ resistant to ampicillin, tetracycline, gentamicin, cefuroxime, ceftriaxone, and cefotaxime, and $100 \%$ susceptible to chloramphenicol. The current findings are in line with work carried out by Ahmadi et al. [61] who reported that $E$. coli isolates from meat and meat product were resistant to ampicillin, tetracycline, and other antibiotics. Barua [62] also reported a higher percentage of VTEC isolates resistant to ampicillin. Additionally, Somda et al. [63] reported E. coli isolates from fumed, grilled, and flamed chicken resistant to cefotaxime (7.14\%), ceftriaxone $(10.71 \%)$, ampicillin $(42.86 \%)$, tetracycline $(64.3 \%)$, and other antibiotics that support the current results. The current findings also agree with work carried out by Apun et al. [64] who reported E. coli isolates from Malaysian broiler chickens resistant to ampicillin, tetracycline, and gentamicin ranging from 11 to $95 \%$. Tricia et al. [65] reported $43 \%$ of E. coli isolates resistant to ampicillin but were not resistant to gentamicin, and this partly agrees with the current findings.

In the case of the $S$. aureus $(n=36)$, majority of them were multiresistant to all the antibiotics tested and only few were susceptible to four of the antibiotics namely ampicillin (2.78\%), erythromycin (25\%), cotrimoxazole $(13.89 \%)$, and gentamicin (30.56\%). Since the S. aureus been multiresistant to the antibiotics tested, the khebabs could pose a health risk to the consumer. The current findings agree with work carried out by Temesgen et al. [66], who reported $S$. aureus isolates from ready-to-eat foods resistant to ampicillin, ceftriaxone, cloxacillin, and other antimicrobial drugs. This therefore makes treatment of $S$. aureus infection difficult.

The E. coli and S. aureus exhibited a similar antibiotic resistance pattern even though the khebab samples were taken from different locations. This agrees with work carried out by Achi and Madubuike [67], who reported similar antibiotic resistance patterns of $S$. aureus isolates from different vendors (hawkers and retail outlets) in food samples. These antibiotic-resistant bacterial isolates from the khebab samples give an indication that street foods might pose serious health problems to the public who patronize them. According to Umoh et al. [68] and Chigbu and Ezeronye [69], the level of antimicrobial resistance is because of the result of indiscriminate use and abuse of antibiotics in the environment. Additionally, the practice of administering antimicrobials agents to domestic livestock as a way of preventing and treating diseases as well as serving as promoting growth could result in the emergence of antimicrobial-resistant bacteria.

In recent years, antimicrobial resistance in foodborne pathogens has been on the rise. According to Allison and Gilbert [70], the increase could be attributed to the selection pressure created by using antimicrobials in food-producing animals and unregulated use of antibiotics by humans in developing countries. De Briyne et al. [71] also indicated the prevalence of resistance to these antibiotics is expected as the result of extensive use of these substances in veterinary medicine. 


\section{Conclusion}

The prevalence of foodborne illness in Ghana is rising each day, which is a major threat to public health. The current research sought to determine the quality of khebabs on the KNUST campus and its environs as well as the antibiotic resistance of $E$. coli and $S$. aureus isolated from the khebabs. The findings of the study generally suggest that streetvended khebabs on the KNUST campus and its environs were contaminated. Isolated E. coli and S. aureus were multiresistant to the antibiotics tested and therefore expose consumers to risk of contracting multiresistant E. coli and S. aureus illness.

\section{Data Availability}

The data used to support the findings of this study are included within the supplementary information file.

\section{Conflicts of Interest}

The authors declare that they have no conflicts of interest.

\section{Supplementary Materials}

The supplementary material contains the raw dataset on MPN count for E. coli, TVC for S. aureus, and antimicrobial susceptibility test on E. coli and $S$. aureus isolates obtained from the beef, chevon, and gizzard khebabs analyzed in the laboratory. The laboratory analysis on each method was replicated three times. (Supplementary Materials)

\section{References}

[1] A. Bagumire and R. Karumuna, "Bacterial contamination of ready-to-eat meats vended in highway markets in Uganda," African Journal of Food Science, vol. 11, no. 6, pp. 160-170, 2017.

[2] O. J. Oje, V. A. Ajibade, O. T. Fajilade, and A. Ajenifuja, "Microbiological analysis of RTE foods vended in mobile outlet catering units from Nigeria," Journal of Advances in Food Science \& Technology, vol. 5, no. 1, pp. 15-19, 2018.

[3] S. Y. Clarence, C. N. Obinna, and N. C. Shalom, "Assessment of bacteriological quality of ready to eat food (Meat pie) in Benin City metropolis, Nigeria," African Journal of Microbiology Research, vol. 3, no. 6, pp. 390-395, 2009.

[4] D. Agbodaze, P. N. Nmai, F. Robertson, D. Yeboah-Manu, K. Owusu-Darko, and K. Addo, "Microbiological quality of khebab consumed in the Accra metropolis, Ghana," Medical Journal, vol. 39, pp. 46-49, 2005.

[5] E. Abebe, G. Gugsa, and M. Ahmed, "Review on major foodborne zoonotic bacterial pathogens," Journal of Tropical Medicine, vol. 2020, Article ID 4674235, 19 pages, 2020.

[6] W. Elmonir, M. E. Abo-Remela, and A. Sobeih, "Public health risks of Escherichia coli and Staphylococcus aureus in raw bovine milk sold in informal markets in Egypt," Journal of Infection in Developing Countries, vol. 12, no. 7, pp. 533-541, 2018.

[7] K. Bantawa, K. Rai, D. Subba Limbu, and H. Khanal, "Foodborne bacterial pathogens in marketed raw meat of Dharan, eastern Nepal," BMC Research Notes, vol. 11, no. 1, p. 618, 2018.
[8] V. B. Hemalata and D. B. M. Virupakshaiah, "Isolation and identification of food borne pathogens from spoiled food samples," International Journal of Current Microbiology and Applied Sciences, vol. 5, no. 6, pp. 1017-1025, 2016.

[9] M. O. Edema and A. M. Omemu, "Microbiology and food hygiene in public food services," in Proceedings of the First International Conference on Science and National Development, 2004 Oct 25-28, I. C. Eromosele, T. A. Arowolo, T. O. S. Popoola, and I. A. Akpan, Eds., pp. 25-29, Federal University of Agriculture, Abeokuta, Nigeria, 2004.

[10] J. F. R. Lues and I. Van Tonder, "The occurrence of indicator bacteria on hands and aprons of food handlers in the delicatessen sections of a retail group," Food Control, vol. 18, pp. 326-332, 2007.

[11] P. Feglo and K. Sakyi, "Bacterial contamination of street vending food in Kumasi, Ghana," Journal of Medical and Biochemical Sciences, vol. 1, no. 1, pp. 1-8, 2012.

[12] J. A. Hennekinne, M. L. de Buyser, and S. Dragacci, "Staphylococcus aureus and its food poisoning toxins: characterization and outbreak investigation," FEMS Microbiology Reviews, vol. 36, pp. 815-836, 2012.

[13] B. A. Diep, S. R. Gill, R. F. Chang et al., "Complete genome sequence of USA300, an epidemic clone of community-acquired meticillin-resistant Staphylococcus aureus," Lancet, vol. 367, pp. 731-739, 2006.

[14] S. Wu, J. Huang, Q. Wu et al., "Prevalence and characterization of Staphylococcus aureus isolated from retail vegetables in China," Frontiers in Microbiology, vol. 9, p. 1263, 2018.

[15] E. Scallan, R. M. Hoekstra, F. J. Angulo et al., "Foodborne illness acquired in the United States-major pathogens," Emerging Infectious Disease Journal, vol. 17, pp. 7-15, 2011.

[16] G. Ekici and E. Dumen, Escherichia coli and Food Safety. The Universe of Escherichia coli, IntechOpen, London, UK, 2019.

[17] M. Blanco, J. E. Blanco, A. Mora et al., "Serotypes, virulence genes, and intimin types of Shiga toxin (verotoxin)-producing Escherichia coli isolates from healthy sheep in Spain," Journal of Clinical Microbiology, vol. 41, pp. 1351-1356, 2003.

[18] Q. Meng, X. Bai, A. Zhao et al., "Characterization of shiga toxin-producing Escherichia coli isolated from healthy pigs in China," BMC Microbiology, vol. 14, no. 5, 2014.

[19] A. M. Monaghan, B. Byrne, D. McDowell, A. M. Carroll, E. B. McNamara, and D. J. Bolton, "Characterization of farm, food, and clinical shiga toxin-producing Escherichia coli (STEC) O113," Foodborne Pathogens and Disease, vol. 9, no. 12, pp. 1088-1096, 2012.

[20] O. Falup-Pecurariu, R. I. Lixandru, E. Cojocaru et al., "Shiga toxin producing Escherichia coli-associated diarrhea and hemolytic uremic syndrome in young children in Romania," Gut Pathogens, vol. 11, p. 46, 2019.

[21] G. Buvens, Y. De Gheldre, A. Dediste et al., "Incidence and virulence determinants of verocytotoxin-producing Escherichia coli infections in the Brussels-Capital Region, Belgium, in 2008-2010," Journal of Clinical Microbiology, vol. 50, pp. 1336-1345, 2012.

[22] T. E. Grys, M. Sloan, J. E. Rosenblatt, and R. Patel, "Rapid and sensitive detection of shiga toxin-producing Escherichia coli from non-enriched stool specimens by real-time PCR in comparison to enzyme immunoassay and culture," Journal of Clinical Microbiology, vol. 47, pp. 2008-2012, 2009.

[23] A. Hosein, K. Munoz, K. Sawh, and A. Adesiyun, "Microbial load and the prevalence of Escherichia coli, Salmonella spp. and Listeria spp. in ready-to-eat products in Trinidad," The Open Food Science Journal, vol. 2, pp. 23-28, 2008. 
[24] S. F. Altekruse, M. L. Cohen, and D. L. Swerdlow, "Emerging foodborne diseases," Emerging Infectious Diseases, vol. 3, no. 3, 1997.

[25] P. I. Tarr, C. A. Gordon, and W. L. Chandler, "Shiga-toxin producing Escherichia coli and haemolytic uraemic syndrome," Lancet, vol. 365, pp. 1073-1086, 2005.

[26] E. Scallan, T. F. Jones, A. Cronquist et al., "Factors associated with seeking medical care and submitting a stool sample in estimating the burden of foodborne illness," Foodborne Pathogens and Disease, vol. 3, no. 4, pp. 432-438, 2006.

[27] O. L. Musa and T. M. Akande, "Effect of health education intervention or food safety practices among food vendors in Ilorin," Sahel Medical Journal, vol. 5, pp. 120-124, 2002.

[28] A. Draper, Street Foods in Developing Countries: The Potential for Micronutrient Fortification, John Snow, INC/OMNI Project London School of Hygiene and Tropical Medicine, London, UK, 1996.

[29] P. Mensah, K. Owusu-Darko, D. Yeboah-Manu, A. Ablordey, F. K. Nkrumah, and H. Kamiya, "The role of street food vendors in the transmission of enteric pathogens," Ghana Medical Journal, vol. 33, pp. 19-29, 1999.

[30] M. Ashenafi, "Bacteriological profile and holding temperature of ready-to-serve food items in an open market in Awassa, Ethiopia," Tropical and Geographical Medicine, vol. 47, pp. 244-247, 1995.

[31] E. Niyonzima, M. P. Ongol, Y. Brostaux et al., "Consumption patterns, bacteriological quality and risk factors for Salmonella contamination in meat based meals consumed outside the home in Kigali, Rwanda," Food Control, vol. 73, pp. 546-554, 2017.

[32] WHO, Background Paper: Developing a Food Safety Strategy", WHO Strategic Planning Meeting, Geneva, Switzerland, 2001.

[33] M. Ghosh, S. Wahi, M. Kumar, and A. Ganguli, "Prevalence of enterotoxigenic Staphylococcus aureus and Shigella species in some raw street vended Indian foods," International Journal of Environmental Research amd Public Health, vol. 17, pp. 151-156, 2007.

[34] L. Yang, Y. Yu, Z. Feng et al., "Multi-drug resistant gramnegative enteric bacteria isolated from flies at Chengdu airport, China," vol. 44, no. 6, pp. 988-996, 2013.

[35] W. S. Darwish, E. A. Eldaly, M. T. El-Abbasy, Y. Ikenaka, S. Nakayama, and M. Ishizuka, "Antibiotic residues in food: the African scenario," Japanese Journal of Veterinary Research, vol. 61, pp. S13-S22, 2013.

[36] P. Papadopoulos, T. Papadopoulos, A. S. Angelidis et al., "Prevalence of Staphylococcus aureus and of methicillin resistant S. aureus (MRSA) along the production cain of dairy products in north-western Greece," Food Microbiology, vol. 69, pp. 43-50, 2018.

[37] P. Sauer, J. Síla, T. Stosová et al., "Prevalence of genes encoding extracellular virulence factors among meticillin resistant Staphylococcus aureus isolates from the University Hospital, Olomouc, Czech Republic," Journal of Medical Microbiology, vol. 57, pp. 403-410, 2008.

[38] B. Huang, Z. Deng, M. Tan, and Y. Liao, "Contamination status, staphylococcal enterotoxin-producing property and drug resistance of Staphylococcus aureus isolated from food products," Chinese Journal of Health Laboratory Technology, vol. 19, pp. 1380-1382, 2009.

[39] H. Gharsa, S. K. Ben, C. Lozano et al., "Prevalence, antibiotic resistance, virulence traits and genetic lineages of Staphylococcus aureus in healthy sheep in Tunisia," Veterinary Microbiology, vol. 156, pp. 367-373, 2012.
[40] A. Ayamah, A. A. Sylverken, and L. A. Andoh, "Assessment of microbiological quality of khebab sold on the campus of a tertiary education and its environs in Ghana," Journal of Microbiology and Antimicrobials, vol. 13, no. 2, pp. 20-26, 2021.

[41] P. F. Ababio and D. D. Adi, "Evaluating food safety practices among food handlers in the Kumasi Metropolis," Internet Journal of Food Safety, vol. 14, pp. 35-43, 2012.

[42] M. Ortiz, "Antimicrobial activity of onion and ginger against two food borne pathogens Escherichia coli and Staphylococcus aureus," MOJ Food Process and Technology, vol. 1, no. 4, pp. 98-106, 2015.

[43] European Committee on Antimicrobial Susceptibility Testing, Breakpoint Tables for Interpretation of MICs and Zone Diameters, version 3.1, European Committee on Antimicrobial Susceptibility Testing, Växjö, Sweden, 2013.

[44] http://www.eucast.org/fileadmin/src/media/PDFs/EUCAST_ files/Breakpoints_tables/Breakpoint_table_v_3.1pdf.

[45] O. A. Egbebi and A. A. Muhammad, "Microbiological analysis of ready-to-eat suya meat sold in Owo, Ondo state," International Journal of Innovative Biochemistry and Microbiology Research, vol. 4, pp. 11-15, 2016.

[46] O. T. Oladipo-Adekeye and F. T. Tabit, "The food safety knowledge of street food vendors and the sanitary compliance of their vending facilities, Johannesburg, South Africa," Journal of Food Safety, vol. 41, no. 4, Article ID e12908, 2021.

[47] E. Carrasco, A. Andrés Morales-Rueda, and R. M. GarcíaGimeno, "Cross-contamination and recontamination by Salmonella in foods," A review, Food research International, vol. 45, pp. 545-556, 2012.

[48] Q. Wei, S. Hwang, and T. Chen, "Microbiological quality of ready-to-eat food products in Southern Taiwan," Journal of Food and Drug Analysis, vol. 14, no. 1, pp. 68-73, 2006.

[49] WHO, "Essential safety requirements for street vended foods," Food Safety Unit, Division of Food and Nutrition, WHO/FNU/FOS/96.7, Geneva, Switzerland, 1996.

[50] F. L. Bryan, P. Teufel, S. Riazj, S. Roohij, F. Quadar, and Z. Malik, "Hazards and critical control points of street-vended chat, a regionally popular food in Pakistan," Journal of Food Protection, vol. 55, pp. 708-713, 1992.

[51] R. D. Djoulde, B. James, and D. Bakari, "Microbiological quality and safety of street meat sold in Soudano, Sahelian zone of Cameroon," International Journal of Current Microbiology and Applied Sciences, vol. 4, no. 2, pp. 441-450, 2015.

[52] A. D. Ologhobo, A. B. Omojola, S. T. Ofongo, S. Moiforay, and M. Jibir, "Safety of street vended meat products e chicken and beef 'suya'," African Journal of Biotechnology, vol. 9, pp. 409-4095, 2010.

[53] M. D. Salihu, A. U. Junaidu, A. A. Magaji et al., "Bacteriological quality of traditionally prepared fried ground beef (dambun nama) in Sokoto, Nigeria," Advance Journal of Food Science and Technology, vol. 2, no. 3, pp. 145-147, 2010.

[54] H. G. Bishop and G. Onyowoicho, "Escherichia coli and Staphylococcus aureus contaminations of carrots sold within Zaria, Nigeria and their antibiotic susceptibility pro'les," Open Access Journal of Science, vol. 1, pp. 110-113, 2017.

[55] U. Gilbert and A. Harrison, "Occurrence of enterotoxinproducing Staphylococcus aureus in meat markets in Nigeria," Journal of Food infection, vol. 56, pp. 25-35, 2001.

[56] L. R. Gay, Educational Research Competencies for Analysis and Application, Merrill Publishing Company, Toronto, Cananda, 1982. 
[57] M. M. Levine, "Escherichia coli that cause diarrhea: enterotoxigenci, enteropathogenic, enteroinvasive, enterohaemorrhagic enteroaldherant," Journal of Infectious Diseases, vol. 155, pp. 377-389, 1987.

[58] I. A. Hassan, H. O. Emun, and E. O. Adekunle, "Microbial quality of ready to eat Barbecue meat (suya) sold on the Streets of Lagos state," International Journal of Advances in Pharmacy Biology and Chemistry, vol. 3, no. 4, pp. 973-982, 2014.

[59] P. Selvan, R. Narendra Babu, S. Sureshkumar, and V. Venkataramanujam, "Microbial quality of retail meat products available in Chennai city," American Journal of Food Technology, vol. 2, pp. 55-59, 2007.

[60] R. E. Uzeh, R. E. Ohenhen, and O. O. Adeniji, "Microbial contamination of tsire-suya-a Nigerian meat product," Pakistan Journal of Nutrition, vol. 5, no. 5, pp. 458-460, 2006.

[61] S. A. Ahmadi, A. K. Panda, Shalmali, Y. Kumar, and H. G. Brahmne, "Prevalence of Escherichia coli and Salmonella spp. in ready-to-eat meat and meat products in Himachal Pradesh," Journal of Communicable Diseases, vol. 44, no. 2, Article ID 71e77, 2012.

[62] R. Barua, "Comparison of PCR vis-à-vis culture method for detection of salmonella and verotoxic E. coli from water and ready-to-eat foods," Thesis Submitted to Veterinary Publichealth, Indian Veterinary Research Institute, Bareilly, India, 2006.

[63] N. S. Somda, Q. J. I. Bonkoungou, C. Zongo et al., "Safety of ready-to- eat chicken in burkina faso: microbiological quality, antibiotic resistance, and virulence genes in Escherichia coli isolated from chicken samples of Ouagadougou," Food Science \& Nutrition, vol. 6, no. 4, pp. 1077-1084, 2018.

[64] K. Apun, Y. L. Chong, M. T. Abdullah, and V. Micky, "Antimicrobial susceptibilities of Escherichia coli isolates from food animals and wildlife animals in sarawak, east Malaysia," Asian Journal of Animal and Veterinary Advances, vol. 3, no. 6, pp. 409-416, 2008.

[65] D. M. Tricia, W. McLaughlin, and P. D. Brown, "Antimicrobial resistance of Escherichia coli isolates from broiler chickens and humans," Biomed Central Veterinary Research, vol. 2, no. 7, 2006.

[66] E. Temesgen, T. Haimanot, D. Derese, and K. Gebre, "Bacteriological quality of street foods and antimicrobial resistance of isolates in hawassa," Ethiopian Journal of Health Science, vol. 26, no. 6, pp. 533-542, 2016.

[67] O. K. Achi and C. N. Madubuike, "Prevalence and antimicrobial resistance of $S$. aureus isolated from retail ready to eat foods in Nigeria," Research Journal of Microbiology, vol. 2, pp. 516-523, 2007.

[68] V. I. Umoh, A. A. Adesiyun, and N. E. Gomwalk, "Antibiogram of Staphylococcal strains from milk and milk products," Journal of Veterinary Medicine B, vol. 37, pp. 701-706, 1990.

[69] C. O. Chigbu and O. U. Ezeronye, "Antibiotic resistant Staphylococcus aureus in abia state of Nigeria," African of Journal of Biotechnology, vol. 2, pp. 374-378, 2003.

[70] D. G. Allison and P. Gilbert, "Modification by surface association of antimicrobial susceptibility of bacterial populations," Journal of Industrial Microbiology, vol. 15, pp. 311-317, 1995.

[71] N. De Briyne, J. Atkinson, L. Pokludová, and S. P. Borriello, "Antibiotics used most commonly to treat animals in Europe," The Veterinary Record, vol. 175, p. 325, 2014. 